\title{
Relationship Between Principal Leadership Styles and Organizational Culture With Work Motivation of MAN and MAS Teachers at Dewantara Subdistrict North Aceh
}

\author{
Zamzami $^{1}$, Yusrizal $^{2}$, Nasir Usman ${ }^{2}$ \\ ${ }^{1}$ Magister Administrasi Pendidikan ProgramPascasarjana Universitas Syiah Kuala Banda \\ Aceh \\ ${ }^{2}$ Prodi Magister Administrasi Pendidikan Universitas Syiah Kuala Koresponden:
}

\{zamzamiabidon@gmail.com\}

\begin{abstract}
This research aims to examine how are the influence of principal leadership style and organization culture on the teacher's working motivation at State (MAN) and Private Senior High School (MAS) in Dewantara Subdistrict. This research uses the quantitative approach with descriptive method. The population in this research is the teachers who teach at State and Private Senior High School in Dewantara sub-district, the sample is 103 teachers. The data analysis method used in this research is multiple linear regressions. The result of the analysis based on the multiple linear regressions shows that $\mathrm{Y}=2.227+$ $0.172 \times 1+0.264 \times 2$. The result of the research shows that partially the principal leadership style variable has strong correlation toward the teachers' working motivation at State and Private Senior High School in Dewantara sub-district in which the regression coefficient value is 0.264 and the test result simultaneously shows that the principal leadership style and the organization culture has correlation toward the teacher's working motivation at State and Private Senior High School in Dewantara sub-district with Fscoreis 15. 815, while Ftableis on the significance level of $\alpha=5 \%$ is 3. 284. The Fscorestatistic test shows that Fscore $>$ Ftable, with the probability level, is 0.000 .
\end{abstract}

Keywords: Principal Leadership Style, Organizational Culture, and Teacher's Work Motivation

\section{Introduction}

Leadership is a very important thing in the management of educational institutions, from this institution human resources will be created to be ready for and capable of competing with local and global situations through education. Education leaders, in this case, are the school's principals, in the hands of these policy holders, the fate of the school is at stake. In leadership there is a relationship between humans, that is, the relationship affects the leader and the obedience-obedience relationship of the followers because it is influenced by the authority of the leader. The followers are influenced by the power of the leader, and arise spontaneously a sense of obedience to the leader. Furthermore, Uha [1] says that "Leadership is the ability to persuade other people to achieve the goals that have been determined by intuition". 
The school is one type of organization that is often called a formal education body. One of the most important elements in its body is its people. The internal personnel of the school organization consists of the headmaster, teachers, students, and administrative staff. The main activity they do is teaching and learning activities. In the context of achieving organizational goals, it is very unlikely that the objectives of an educational institution can be achieved without the existence of a cooperative effort of all organizational personnel and supported by sufficient facilities and infrastructure. Education leaders as top leaders in an educational institution formulate and communicate a clear vision and mission in advancing education.

The principal is an education unit level of education leader, who must be responsible for all school activities. Besides that, the principal is an education leader whose position is very important in the school environment, because the principal is closer and directly related to the implementation of each education program. Therefore, principals are required to have various abilities, both the ability to link with management and leadership issues, so they can develop and advance their schools effectively, efficiently, independently and productively. Furthermore, Hendarman [2] states that "Principals as managers of education units (schools) are responsible for the effectiveness and efficiency of implementing education in their schools, through the roles they play". Whether or not an education program can be implemented and the purpose of education can be achieved or not depends on the skills and wisdom of the school's principal as the leader of education.

Besides the schools' principal, a teacher is a person who is very influential in the teaching and learning process. A teacher has several important roles because it has responsibilities that cannot be replaced by any other sophisticated types of equipment. Therefore the teacher can ideally prepare himself as a teacher who remains progressive and productive in all learning processes. In relation to the personality of the teacher he/she carries out, always putting his professionalism in line with having a good personality or knowledgable that is appropriate and can be an example in all daily life activities both in the school environment, family, and the community. Because in the hands of teachers the progress and the glory of a nation rely on.

The efforts made by the principals in optimizing the use of existing personnel, one of which is teacher empowerment. Empowerment, in this case, is intended as a way or effort of the principal in developing potential and encouraging the power possessed by the teacher to be able to work and work as much as possible to achieve the stated goals. According to Susanto [3] "Empowerment of teachers is one of the steps taken by principals in optimizing teachers so that they are able to provide good performance until finally, they can offer more effective and efficient services". The development carried out by the principal of the school personnel, especially the teacher, is a step in preparing teachers to be more competent to contribute to improving work productivity, especially in the teaching and learning process.

In carrying out the task of educating students, teachers have different traits and behaviors, some are enthusiastic and full of responsibility, there are also teachers who often skip truant, come in time and do not obey orders. These kinds of the condition are a problem in every formal education institution. With the existence of teachers who have low performance, the school will find it difficult to achieve expected goals. A good teacher's performance will be achieved when principals are able to communicate, coordinate and supervise regularly.

Thus the leadership style of the principal in leading will have an impact on teacher performance and in terms of creating a conducive atmosphere for the school environment. Therefore the leadership style used must be right. Susanto[3] explains that: "The leadership style of a leader can basically be explained through three streams of theory, namely genetic theory, social theory, and ecological theory". Furthermore, Hersey and Blanchard [3] argue that "The 
leadership style is basically the embodiment of three components, namely the leader itself, subordinates, and situations where the leadership process is realized".

The success of education in schools is largely determined by the success of the principal in managing the educational staff at the school. The principal is one component of education that has an influence on improving teacher performance. The view that principals as a determining factor in improving the quality of education is explained by Mulyasa [2], that "Principals are responsible for the implementation of education, school administration, coaching of other education personnel, utilization and maintenance of facilities and infrastructure as well as supervisor at the school he leads". This becomes more important in line with the increasingly complex demands of school principals, who want more effective and efficient performance support.

Work motivation is one of the factors that determine the performance of a teacher. The amount or the influence of motivation on teacher performance depends on how much motivation is influenced by internal and external dimensions. Robbins [4] defines "Motivation as a process that shows the individual intensity, direction, and perseverance of efforts towards achieving goals".

The teacher becomes an educator because of the motivation to educate if he does not have motivation he will not succeed in educating or teaching.

Based on the results of interviews conducted by the authors with several MAN and MAS teachers in the North Aceh District, there was information that most teachers had difficulties in making syllabus and lesson plans, lack of discipline emphasized to the teacher, unvaried use of learning methods and strategies, inability to compile evaluation tools, classroom management activities, and lack of ability to determine approaches and methods of evaluation.

Thus, it is strongly assumed that the principal's leadership style, organizational culture, and work motivation are key factors that can influence teacher performance in school. The school will succeed if it is supported by the leadership quality of the principal and a good organizational culture and is supported by good work motivation. With the existence of teachers who have low performance, the school will find it difficult to achieve results as expected by the organization.

\section{Research Methods}

\subsection{Research Design}

This research is classified as quantitative research in the form of a correlational study to examine relationship both directly and indirectly. Usually, the size of the relationship is expressed in numbers called relationships or correlation coefficients. Correlation coefficient moves between 0.289 to +0.704 or between 0,000 to 1,000 , depending on the direction of the correlation, nil, positive or negative. Positive signs indicate a negative correlation direction. Whereas, the coefficient that is -0.001 shows no correlation between $\mathrm{X}$ and $\mathrm{Y}$ [5]. Correlation research, intended to determine whether there is a relationship between the school principal's leadership style and organizational culture with the motivation of MAN and MAS teachers in Dewantara Subdistrict, North Aceh.

\subsection{Population and Samples}

What is meant by population and sample are people, objects or documents that can provide the data needed to prove the research hypothesis stated above. So, the population and sample in this study were all MAN and MAS teachers in Dewantara Subdistrict, North Aceh totaling 103 people. Because the number of sample members is limited and only in one school, saturated 
samples are not taken. This means that all members of the subject were used as research respondents.

\subsection{Data Analysis}

Technical data analysis is a technique used in research with the intention to test and draw a conclusion from the results of the test. Data analysis was used to determine the existence or absence of a relationship between three variables, namely the relationship between the principal's leadership style and organizational culture with the motivation of MAN and MAS teachers in Dewantara Subdistrict of North Aceh.

\section{RESULT AND DISCUSSION}

3.1 Analysis of the relationship between School's Principal Leadership Style and Organizational Culture on Teachers' Work Motivation at MAN and MAS Dewantara Subdistrict, North Aceh.

Based on the results of the analysis, it reveals that organizational culture variables have a dominant influence on the motivation of MAN and MAS teachers in Dewantara Subdistrict, North Aceh Regency, with a regression coefficient of 0.172 having a dominant influence on increasing MAN and MAS teachers' work motivation in Dewantara Subdistrict, North Aceh Regency. Whereas, the variable of the principal's leadership style had a relatively lower influence on teachers' work motivation with a regression coefficient of 0.264 .

\subsection{Correlation Coefficient and Determination}

The Correlation coefficient $(\mathrm{R})=0.700$ which indicates that the degree of relationship (correlation) between the independent variable and the dependent variable is $70.0 \%$. This means that the motivation of MAN and MAS teachers in Dewantara Subdistrict, North Aceh Regency has a close relationship with the principal's leadership style variable (X1), organizational culture (X2) so that both variables have an influence on increasing MAN and MAS teachers' motivation in Dewantara Subdistrict, North Aceh Regency.

The Determination Coefficient $\left(\mathrm{R}^{2}\right)$ is 0.489 . This means that $48.9 \%$ of changes in the dependent variable (motivation of MAN and MAS teachers' in Dewantara Subdistrict, North Aceh) can be explained by changes in the principal's leadership style factor (X1) and organizational culture (X2).

While the rest, which is equal to $51.1 \%$, is explained by other factors outside of the two variables used as indicators of research, meaning there are still variables that can affect the motivation of MAN and MAS teachers in Dewantara Subdistrict, North Aceh Regency. Variables outside of this study can be predicted such as teachers' education level, continuous training program (MGMP), school environment factors, competence, and teaching and learning supporting facilities in MAN and MAS Dewantara Subdistrict, North Aceh Regency, are expected to increase teachers' motivation.

The results of this study indicate that the principals'leadership style and organizational culture both jointly and partially can influence the motivation of MAN and MAS teachers' in Dewantara Subdistrict, North Aceh Regency, so that the leadership style of MAN and MAS principals in Dewantara Subdistrict, North Aceh needs to get attention from the leadership, in this case, the headmaster and Head of the North Aceh District Youth and Sports Education 
Office can be improved through continuous training programs. Also, the organizational culture should also be a concern of the principal which can give an impact both directly and indirectly on increasing motivation for MAN and MAS teachers in Dewantara Subdistrict, North Aceh Regency.

The results of this study support the theory that has been carried out by Nurmalina[6], that the leadership style of the teacher-principal can influence the increase in teacher motivation. This is because the presence of the principal's leadership style that is applied by the principal will have an impact on increasing teacher motivation. With the application of the leadership style of the principal, is expected to be accepted by all teachers and students in order to increase work motivation.

Likewise, the organizational culture can also support the increase in teacher work motivation, this is in line with the results of a research conducted by Fatmawati[7], that organizational culture will have an impact on increasing teacher's work motivation because of the new responsibilities in carrying out tasks and responsibilities as a teacher.

\section{CONCLUSIONS AND SUGGESTIONS}

\subsection{Conclusions}

1. The partial test results of principals' leadership style variables have a significant influence on teachers' work motivation at MAN and MAS Dewantara Subdistrict, North Aceh Regency with a regression coefficient value of 0.172 .

2. The partial test results of organizational culture variables also have a significant influence on the teachers' motivation at MAN and MAS Dewantara Subdistrict, North Aceh Regency with a regression coefficient value of 0.264 .

3. While the results of the simultaneous testing also show that the principal leadership style variable and organizational culture have a significant influence on the teachers' motivation at MAN and MAS Dewantara Subdistrict North Aceh Regency by obtaining a Fcount value of 15.815, while Ftable at a significance level $=5 \%$ is 3,284. Based on the calculation of the Fcount statistical test shows that Fcount> Ftable, with a probability level of 0.00 .

\subsection{Suggestions}

1. To improve teacher's work motivation, the role of the principal in giving instructions and direction to the teacher should be conducted continuously, this is because not all teachers have the same ability to carry out the teaching and learning process.

2. The results of this study indicate that MAN and MAS teachers in Dewantara Subdistrict, North Aceh Regency have high work motivation and it is expected that principals continue to provide work motivation to teachers so that they can carry out the teachinglearning process better.

3. It needs further research using a different approach, because of the limited interpretation of the phenomena obtained in this study that might not be able to explain in depth. This is because this study uses a quantitative approach so that it is more focused on the results in the form of numbers. Besides using other variables that can affect the motivation of teacher work by teachers at MAN and MAS in Dewantara Subdistrict, North Aceh Regency. 


\section{REFERENCES}

[1] I. N. Uha, Budaya organisasi kepemimpinan dan kinerja. Proses terbentuk, tumbuh kembang, dinamika, dan kinerja organisasi. Depok: Kencana, 2017.

[2] Hendarman, Revolusi kinerja kepala sekolah. Jakarta: Indeks, 2017.

[3] A. Susanto, Konsep, strategi, dan implementasi manajemen peningkatan kinerja guru. Jakarta: Prenada media Group, 2016.

[4] D. J. Priansa, Kepala sekolah dan guru profesional. Bandung: Pustaka Setia, 2017.

[5] S. Hadi, Metodologi Research 2. Yogyakarta: Andi Offset, 2006.

[6] Nurmalina, "Pengaruh motivasi kerja dan pengalaman mengajar guru bersertifikasi terhadap kemampuan melaksanakan pembelajaran pada Madrasah Aliyah kabupaten Bener Meriah,” Universitas Syiah Kuala, 2013.

[7] Fatmawati, "Pengaruh kemampuan profesional dan motivasi kerja guru terhadap prestasi belajar siswa pada SMA Negeri 13 Banda Aceh,” Universitas Syiah Kuala, 2014. 